\title{
Second-Sight in Lincolnshire.
}

\section{Mabel Peacock}

To cite this article: Mabel Peacock (1917) Second-Sight in Lincolnshire., Folklore, 28:3, 326-326, DOI: 10.1080/0015587X.1917.9718999

To link to this article: http://dx.doi.org/10.1080/0015587X.1917.9718999

$$
\text { 册 Published online: } 01 \text { Feb } 2012 .
$$

Submit your article to this journal 준

Q View related articles $\sqsubset$ 
being the thieves. Such a tale, though told of a man of the nineteenth century, may have come down from remote ages. But why were the cows at Cadney so manifestly troubled by the presence of Erinaceus Europaeus?

Hedgehogs, in Lincolnshire, are supposed to carry off fruit impaled on their spines. A young man once told me that when he was living as groom with a doctor who had an orchard, apples began to disappear in a manner which could not be accounted for. Finally, he and several other people observed a hedgehog with apples stuck on its prickles. On being cross-questioned the young man added that there could be no mistake, for he and his companion had a clear view of the animal.

A similar story is told of the porcupine in countries of which it is a native, but I cannot recollect the details.

Mabel Peacock.

\section{Second-Sight in LincolnshiRe.}

Is it usual for people with second-sight to have more than one vision with regard to a person about to die?

On May 15th, 1917, I was told the following story by a Lincoln. shire woman: "My brother says he saw things before his first wire died. He was out with the sheep one night, and a coffin came past him, just as if it had legs (here the narrator made a gesture with her hand about eighteen, or twenty, inches from the ground, as if to show how high the coffin stood). After that, one day in the garden, he saw her in a black dress, and thought that she had got cleaned very early (i.e. that she had finished her heavy work, and made her afternoon toilet), but when he went into the house she hadn't got cleaned, she was doing up the fire. Very soon she died of blood-poisoning after the birth of a baby."

The brother had these visions "about thirty years ago," in the wapentake of Aslacoe. Ordinary ghost-seeing is still not unusual in Lincolnshire, but the faculty of seeing the disembodied spirit of a person yet alive is not often mentioned.

Mabel Peacock. 